\title{
Tenure of Urban Land: Structure, Form and Transformation in Ribeirão Preto, Brazil
}

\author{
Ivone Salgado and Dirceu Piccinato Junior \\ CEATEC (Center for Exact Sciences, Environment and Technology), Pontifical Catholic University of Campinas, Campinas 13090 \\ 610, Brazil
}

\begin{abstract}
The purpose of this study is to explore the urban morphological aspects of cities governed by the juridical regime of emphyteusis, a recurrent situation in the northeastern part of the state of São Paulo, Brazil, with special attention to the city of Ribeirão Preto. The concession of lands to the Catholic Church was a recurring practice in Brazil during the colonial and imperial periods, when the cities were being established. As these lands were intended for the formation of patrimonial goods to show the devotion of the residents to a Catholic saint, the lands were not allowed to be commercialized. The tenure reveals a relation in which there is an owner — the landlord — who has direct control of the urban land. This owner allows another — the leaseholder - the useful domain of the land, thus giving the latter the right to use the land, the obligation to pay an annual tax and the responsibility to give the owner a percentage of the sales generated from the land. In 1845, farmers donated a tract of land to be used to glorify São Sebastião. This land is now the city of Ribeirão Preto, and it is this conjuncture that defined the structure and the transformation of the original urban form of the current city.
\end{abstract}

Key words: Tenure, emphyteusis, urban land, Catholic Church, urban morphology, concession of lands.

\section{Introduction}

As the city is a complex object that manifests various phenomena and interactions, various social sciences have converged in the study of urban forms. The urban form is the result of a range of factors, elements, junctions and conflicts that are more than the sum of their parts. In this way, the complexity and organization of the urban system make the city a specific object to be understood by the cross confrontations of the questions and answers of the human sciences [1].

The term "urban morphology" is not restricted to a single science but rather to numerous sciences, including sociology, anthropology, history, geography, architecture and urban planning, among others, when consistent with a new perspective, thus pointing to new ideas and new understandings. Studying the various aspects of urban form, Kropft [2] showed that

Corresponding author: Ivone Salgado, Ph.D., professor, research fields: urban history, urban form and history of town planning. the diversity and complexity of cities reflect a variety of ways to understand them, which, consequently, have resulted in the elaboration of different research methods and approaches to study the morphology of cities.

In short, the term "urban morphology" refers to the study of the physical form of a city. However, considering that the city is a socially diverse entity, every society seeks to reproduce exterior forms, whether permanent or not. This means that these forms obey a given socio-political order of the group which creates them and that they respond to a functional and effective sociability that also regulates the use of the city space and the resources contained within that space, thus defining their own models of appropriation of the city [3]. Thereafter, the full character of a social process in configuring the urban form can be considered in the studies of urban morphology.

With respect to certain aspects of urban form, Kropft [2] pointed to its definition, which has its 
parameters as the work Good City Form by Lynch [4], in which Lynch identified six distinct aspects. The first refers to the physical form; The second condenses the use, activities and movement of the form; The third addresses control; The fourth relates to perception; The fifth presents the process of continuity or change; The sixth refers to the flow of materials and information. These are the main aspects that must be observed when conducting a critical analysis of urban morphology.

Kropft [2] discussed urban form in the context of a relatively recent time with the aim of establishing a better understanding of the urban configuration. When we look to Brazil in an attempt to list the aspects that outline the urban form of Brazilian cities, the study of urban morphology, according to this methodology, should consider the local social, cultural, geographical and historical contexts of the cities.

According to Vasconcelos [5], when examining the morphology and various aspects of the urban form of Brazilian cities, it was possible to identify modeling agents that were jointly present in the urban setting. However, during the subdivision of this examination into a case-by-case study, it was possible to identify the presence of, if not most, at least one agent that was common to all cities. Five modeling agents were identified. The first was the State, especially at the upper level, i.e., the Portuguese Crown, which played a key role in the implementation of the first towns and cities in Brazil as the Portuguese Crown sought to manage its colony through orders sent directly by the metropolis. The second agent was the Church, whose decisive role was tantamount to that of the state with respect to the structure of Brazilian cities. The Church in Brazil was founded on the patronage system following an agreement between the Vatican and the Portuguese Crown. The Church counted on the presence of the secular clergy, which, as the highest order of the Church, included bishops, archbishops, ecclesiastical courts and seminaries, and the regular clergy, which comprised religious male and female orders. The third agent was the lay orders, which were Catholic institutions that were relatively independent of the official Church and were formed by volunteers of laymen and laywomen. The fourth agent referred to economic agents or external economic agents, who were land owners and domestic economic agents, such as traders, financiers, slave traders and craftsmen. The fifth agent involved the population and social movements. The population was composed of employees, especially staff, masters of letters, surgeons, as well as the poor, the freed and the slaves (until the year of 1888 when slavery was abolished in Brazil). The social movements were extremely important to the national history due to the various uprisings and rebellions articulated by dissident social groups.

The present case study highlights the role of the Church as the authorizing agent of urban form. The morphological urban aspects of cities, governed by the juridical regime of emphyteusis, which is recurrent in the northeastern part of the state of São Paulo, Brazil, are explored with special attention to the city of Ribeirão Preto.

\section{Urban Morphology: Some Considerations}

In recent studies, the understanding of urban morphology presents diverse perspectives of methodological approaches from the assessing of the physical forms of the city and the listings of the fundamental elements, streets, lots and buildings [6] to the describing and prescribing of the urban forms according to a multidimensional, systematic, exploratory and quantitative environment [7]. Studies of multidisciplinary discussions about urban morphology have resulted in the acceptance of the relevancy of the social sciences and humanities with respect to the construction of urban form [8]. In some studies, as noted by Kim [9] regarding the urban form of South Korea, it is possible to observe a particular focus on the formal aspects of cities and towns wherein the parameters of analysis are the history and 
the influence of European morphology in the country. A variety of models of urban forms are examined through a cultural perspective in which the construction of the form is the result of theory and practice, and thus the representations of a particular culture and the historical conditions of the form are described [10].

These various methodological approaches to study urban morphology point to the fact that the analysis and understanding are configured according to the interdisciplinary relations of science, with different views, as well as specific economic, cultural and social conditions of a country or a city. In this sense, this work intends, similarly to Ehlers [10], to discuss the structure, shape and transformation of the urban form of the city according to the social and political articulations in the representation of the its physical form.

As the urban environment is subject to multiple readings, the instruments of analysis draw attention to the phenomena involved in the production of the space. This suggests that the numerous meanings associated with the city and its architecture correspond to numerous conflicts and agreements that helped, directly or indirectly, in the configuration of the urban form.

Lamas [11] noted that the morphological study does not address the urbanization process, i.e., the social phenomena and the economic and other engines of urbanization. Rather, according to the Lamas [11], these "engines" converge in the morphology and in the explanation of the production of form, but they are not the objects of study. However, the study of urban morphology is a cumulative process in which every temporal dimension identifies a result and a possibility, and therefore, it is a continuous movement. Accordingly, we question whether every urban formation is also a social formation in that the latter necessarily spatializes itself [3].

The field of morphologic study is characterized in its entirety as a place of transformation produced by man or as a place of architectural and urban intervention. This means, "man lives in an environmental continuity, and urban or territorial forms are constituted by the composition of different spatial units and morphological elements" [11].

The morphological elements are directly related to urban size and can be identified by the form. Thus, the analysis of this form requires movement and pathways. Lamas [11] identified these elements as the soil, the buildings, the lot (land parcel), the block, the architecture, the layout (the street) and the square, among others that define and explain the urban landscape and its structure.

In general trends of urban formations in colonial Brazil, social confluences were evident in the donation of a strip of land for the establishment of patrimonial goods, and it was on such land assets that the vast majority of Brazilian cities were developed. The city of Ribeirão Preto is no exception to this, as the strip of land on which Ribeirão Preto exists was granted to a saint of Catholic devotion, thereby establishing its religious heritage. Thus, it is possible to identify the concept of urban form, one that is produced by social connections and/or political conflicts on a pre-defined area-the soil.

\section{Formation of the Religious Heritage of Ribeirão Preto}

The formation of cities in Brazil, according to some researchers, should not be analyzed in a systematic, gradual or regimented way but must be considered in light of two standards-"parsimonious and generalizing" [12] —or in the observing of general trends in the configuration of the Brazilian urban form [13]. This situation is explained by the fact that the formation of cities was determined by the prevailing political and economic interests of the important men of the locality [14]. One element, the religious heritage, was common in the formation of urban space in Brazil during the colonial period (1500 1822), imperial period (1822 1889) and part of 
the first republic (1889 1930).

This religious heritage emerged in Brazil in a discrete way. It constituted a tract of land that allowed for the construction of the chapel and for the external space, as recommended by the First Constitutions of the Archbishop of Bahia for the formation of houses to shelter the small sesmeiros. This gave rise to what would be the future urban core. The sesmeiro was the person to whom the sesmaria was granted, and the sesmaria was a Portuguese legal principle that regulated the distribution of land for cultivation in colonial Brazil. "On one hand, it occupied a predetermined ground and planted the desired temple; On the other hand, it propitiated the agglomeration of houses and businesses" [12].

The territorial plots tended to be large during the colonization of Brazil, which hindered the full use of these plots because of the high costs and charges. Thus, many of the settlers ended up not having access to land, while those who had the resources could acquire lands. This resulted in the poorer settlers forming large contingencies or "clusters" that then became owners of large tracts of land.

In the formation of the city of Ribeirão Preto, Lages [15] reported that the religious heritage of the city was dedicated to São Sebastião and that the strip of land was donated by many owners in the years 1852, 1853 and 1856 (Table 1). The relevance of this nonproprietary population was important for the productive sector, which is why the religious heritage arose tentatively, but effectively, in the context of the formation of urban form.

As land extensions were granted by one or more landowners, the disadvantaged workers began to settle in the area. However, the granting of this strip of land did not directly benefit this group of individuals but, rather, benefitted the Catholic saint of devotion, as the administrative care of this patrimony was the compulsory responsibility of the Church [16]. With respect to Ribeirão Preto, it was possible to identify the boundaries of the religious heritage of the city through the information about the blocks that were properly listed together within the Archdiocese of Ribeirão Preto and the 1st and 2nd notary real estate registry (Fig. 1).

At the time of the transcription of the donation, it was common for the donor or donors to request a specific religious endowment as compensation for the act, such as a mass after death, a select burial site, etc. [17].

The administration of this heritage was under the care of the Church Factory, which constituted an entity formed by the religious. The rich men of the town were jealous of the goods of the parish and of the disposing of lands donated in urban form that were assigned under the jurisprudence of the long lease institute or the tenure of those interested in maintaining the balance of land. The term "Factory" comes from the factory manufacturing idea of the Church-its construction, beautification and purchase of ornaments. Thus, it was where issues related to the tenure of the resources of urban land were to be addressed [17].

Once established as the patrimony of holy devotion, local people gathered to build the first building-the chapel. This could not be built just anywhere, according to the First Constitutions of the Archbishop of Bahia, but must be built on a "high and decent place,

Table 1 List of donors of land for the development of the patrimonial goods of São Sebastião of Ribeirão Preto.

\begin{tabular}{llll}
\hline Donors & Farm & Extension (acre) & Date \\
\hline João Alves da Silva and Ana Delfina Bezerra & Retiro & 30 & December 19, 1852 \\
Severiano João da Silva and Gertrudes Maria Teodora & Retiro & 12 & March 16, 1853 \\
José Borges da Costa and Maria Felizardo & Retiro & 9 & March 20, 1853 \\
Inácio Bruno da Costa and Maria Izidora de Jesus & Retiro & 9 & April 19, 1853 \\
José Borges da Costa and Maria Felizarda & Retiro & 12 & March 20, 1853 \\
José Alves da Silva and Pulcina Maria de Jesus & Barra do Retiro & 2 & March 18, 1856 \\
\hline
\end{tabular}




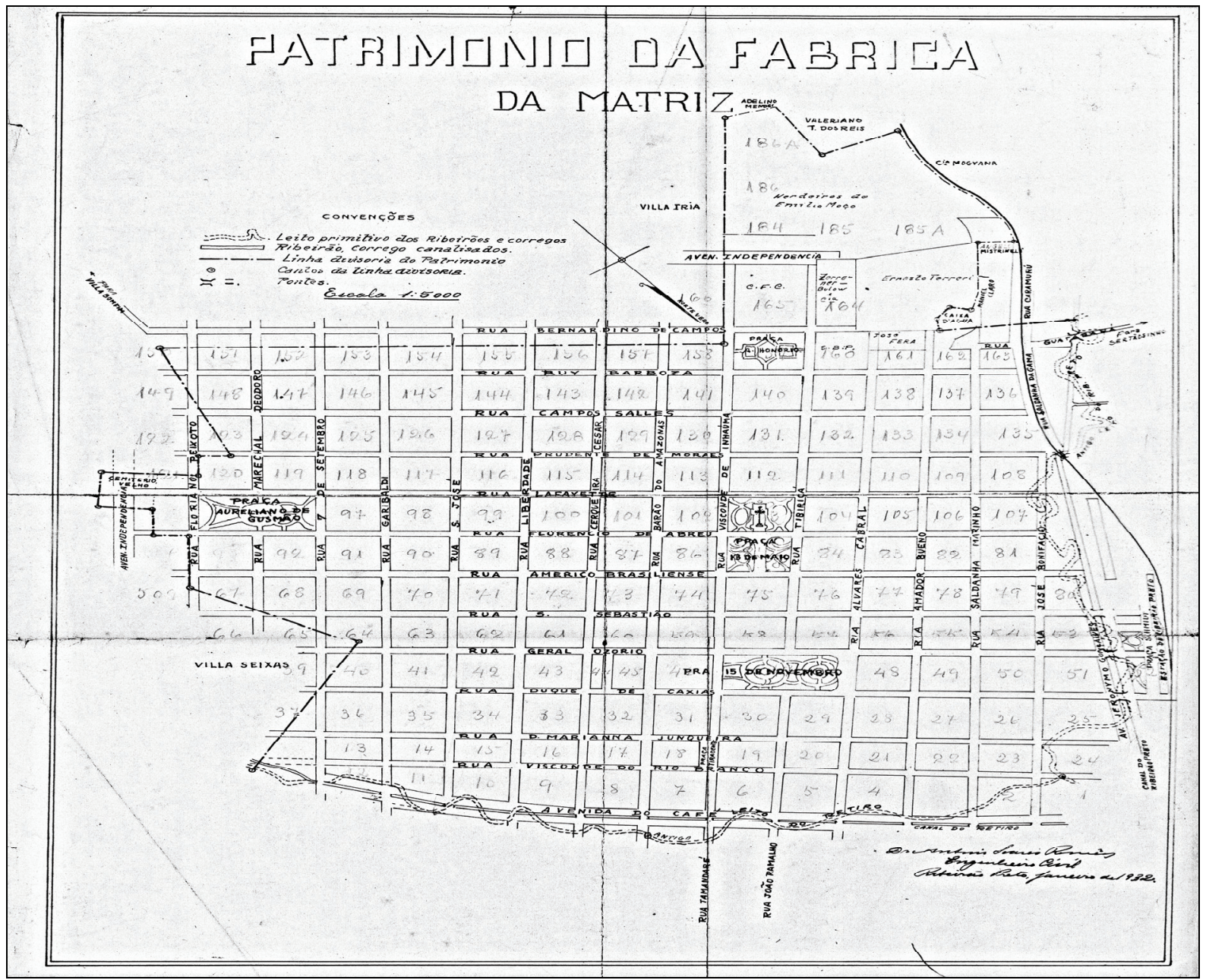

Fig. 1 Patrimonial goods of the Mother Church of São Sebastião of Ribeirão Preto, 1932. The limits of the patrimonial lands in the urban form where the city was originated are highlighted, and it is possible to observe the blocks slightly listed (Public Archives and History of Ribeirao Preto).

free from humidity, private homes and other walls in a distance in which the processions could walk by without impediments..." [18]. At this time, the religious building and its urban status were defined as a chapel.

With the increase in population, the inhabitants of the chapel could ask the ecclesiastical and civil institutions for the elevation of its urban condition to a parish. While the elevation in status from a chapel to a parish took into account demographic and economic criteria, it was the political interests that prevailed [14].

In this new urban condition, the criteria for the location of the Mother Church were not necessarily the same as those for the first chapel. Rather, the criteria could be changed to better meet the interest of the local residents as it was the case in Ribeirão Preto. The modest chapel underwent several reforms to become the main church, a prestigious place where religious events were conducted and citizens meetings were often held.

Once attaining a certain level of power and strength, the parish could ask the civil and religious powers for a promotion in status from parish to village. With such an elevation in status, came "...political autonomy, the status of a municipality" [12]. Under this new title, it became the responsibility of the village to define itself, as it was now a territory comprising chapels, parishes and neighborhoods and, as such, was under the control of a city council. It was now also up to the village to identify and define a park-a smaller 
geographical area to be divided into plots that would integrate the assets of the city council. "This could divide them into 'grounds' (lots) and grant them, upon payment of annual pension, to the residents who asked for them to build their homes" [13].

With respect to religious heritage, "property" of the Saint, which was managed by the Church, was superimposed on a new demarcation - the park, which constituted public land. A conflict, however, arose between the civil and religious powers about land ownership, a situation that was resolved by the overlapping of civil power over religious power in most Brazilian cities. However, in other cities in the northeastern part of the state of São Paulo, the conflict still remains today [19]. The city of Ribeirão Preto is a case in point.

Thus, in the composition of the Brazilian urban landscape, religious buildings outlined the structure and defined its form. The presence, poise, refinement and, especially, the privileged position in which were placed the religious buildings made them the ordering agents in the urban form of both small and large agglomerations [20]. What is observed is the result of the pragmatism and constructive need that initially demanded a simplification of procedures, tracts and architecture. Accordingly, these principles can be considered as a condition for the innovation and transformation of urban form [21].

The title of city was usually only assigned to those villages that performed important religious, political or military roles. Thus, the term was not attributed only to the bishopric seats but also to towns on the coast and in border areas that incorporated high squares [13]. The difference between towns and cities was, therefore, judicial in character and not necessarily hierarchical [16].

\section{The Institute of Long Lease}

The institute of tenure or long lease of land is a legal instrument that was formulated in ancient Greece and later assimilated into the Roman Empire to legitimize the use and retention of workers on the ground. During the Middle Ages, Portugal included this instrument in its set of laws. The first reference was in the Afonsina Ordinances (1500 1514), it was then instituted again in the Manuelina Ordinances (1514 1603) and finally in the Filipina Ordinances (1603 1916). The latter prevailed in Brazilian lands until the year 1916 when it was enacted in first civil code, which recognized the right of long lease. This code remained until 2002, when a new civil code was formulated, but little change about tenure was introduced in the new code. For this study, the civil code of 1916 was used as a source of analysis because it recognized tenure as a right, and it remained in effect until the beginning of the XXI century.

The long lease or tenure is a way to divide the property of a perpetual contract as holder of the long lease gives others the powers of use, enjoyment and disposition, and only transfers them to third parties with his approval.

The long lease can only occur in uncultivated lands or in lands intended for building as stated in article 680 of the civil code. Therefore, it is not possible to establish long lease on the mobile natural goods of the land, on buildings already constructed or on plots already colonized. In this sense, the economic purpose of the long lease is to encourage the use of uncultivated or unbuilt lands.

The institute of tenure or long lease is a territorial alienation contract that divides the ownership of a property into two domain types - the direct domain (imminent) and the indirect domain (useful). This means that there are necessarily two people- the direct landlord who owns the property and the copyholder who acquires real rights. The first is the holder of the domain, while the second has the rights of possession, use and disposal, although these rights are subject to certain limitations for the benefit of the direct landlord [22].

According to Amorin [23], in Brazil, the lands tenured by private personnel have as their landlord the 
Church, its religious orders and the religious institutions established by them. Additionally, there is still the imperial family (urban land in the city of Petrópolis, RJ) and some hundreds of individuals who make up the following assemblages: $60 \%$ are tenured lands held by the Church; $30 \%$ are public lands; $3 \%$ remain the property of the former royal family; The remaining $7 \%$ belong to private individuals. The significant percentage of tenured lands held by the Church shows how common the use of ecclesiastical power was in the formation and of urban form.

Peculiar to the long lease is the payment of an annual pension, the value of which was a small, symbolic amount. In many cities, this practice was abolished, unlike that of the laudêmio.

The laudêmio was a compensation that was to be paid directly to the landlord for not having exercised the right of a purchase option. It is the obligation of the seller, not the buyer, to pay the laudêmio. It is important to clarify that in the buying and selling process what was being negotiated was the right to use the land, not the right to own it.

In Ribeirão Preto, when a resident of heritage land wanted to sell the property, he would transfer to the new owner only the right to use the land because it was the Church that held ownership of the land.

The laudêmio was prepaid, the deed of sale was not tilled and the letter of auction was not issued without having resolved the mentioned tribute. The value of laudêmio was $2.5 \%$ of the total value.

The tenure of urban land in Brazil has long been one of the agents of the configuration of urban form. Many churches, such as that of Ribeirão Preto, maintain on file the books of tenured lands wherein the clerics wrote down the granting of urban land and the payment of taxes (forum or board and the laudêmio). Such records directly contribute to the identification and establishment of the structure, the shape and the urban transformations of the city. These are historical documentary sources that decode and crystallize urban morphology.

\section{Ribeirão Preto and Its Morphological Conditions}

During the 16th, 17th, 18th and 19th centuries, occupying unoccupied and uncultivated lands became a normal behavior among those who wanted to settle. Thus, it could be considered, according to Lima [24], as a "legitimate way of acquiring domain at first, and after in replacing the distorted system of land grants, sesmarias". In this way, the many squatters living throughout the Brazilian lands during the Empire (XIX century), already occupied but were not yet integrated into the agrarian export economy. A recurring output for these men, who had no titles, was the foundation of a chapel with a saint of devotion. The granting of land to the Church for the establishment of a religious heritage was a way of regularizing possession of the land.

Under such conjecture, Lages [15] and Garcia [25] agree with the view that the donation of lands to integrate the heritage of São Sebastião of Ribeirão Preto, the saint of devotion of the locals, was beyond the religious context, that is, the residents had a strategy to legitimize and regulate the possession of the land possession

According to Lages [15], Garcia [25] and Costa [26], there were two attempts to donate to the formation of the heritage that failed because of the lack of documents proving the legitimacy of the land. The first attempt occurred in 1845 and the second in March 1852. It was not until July 1852 that Ribeirão Preto was divided into the lands of two farms - Retiro and Barra do Retiro (Table 1).

Once, the patrimony and granting of the lands for the development of the urban form of Ribeirão Preto in the land of São Sebastião was constituted, it was essential to nominate a vestryman, who would oversee the patrimonial lands and manage the parish goods. While Costa [26] referenced Manuel de Nazareth Azevedo, Manuel Fernandes do Nascimento was an important figure dating back to the first donations as he was the witness and signer for those donors who 
could not read and not write.

According to Garcia [25], from 1859, the responsibility of caring for the territory, tracing the first streets and building a chapel in honor of the patron saint was entrusted to Manuel Fernandes do Nascimento. However, Garcia [25] noted that there is no document that effectively proves that the tracing and the division of lots of the urban territory were actually carried out by Manuel Fernandes do Nascimento.

Lages [15], Costa [26] and Laureano [27] claimed that even before the final regularization of the third and final donation, the residents of the Retiro farm had built a temporary chapel. This small chapel was located in front of the current Rio Branco Palace, where today stands City Hall.

The courtyard opened to build this modest church and comprised the Viscount Inhaúma, General Osório, Cerqueira Cesar and Duque de Caxias blocks, and the chapel was located on the block made up of Barão do Amazonas, General Osório, Cerqueira Cesar and Duque de Caxias streets (Fig. 2).

According to Laureano [27], it was around this chapel that "emerged the first roads and the first buildings, still primitive, of a village". Lages [15] added that, at this time (in 1857), according to an analysis of the packet of voters of the Historical Archives of the state of São Paulo, there were 23 residents who, according to their annual income, were eligible to vote. However, the number of residents was certainly much greater, though at this time, slaves and women could not vote.

In the $1860 \mathrm{~s}$, the population of the farms near the village of São Sebastião of Ribeirao Preto grew considerably, while the core of the local population remained modest. However, Costa [26] identified, in the person of the vestryman Manuel Fernandes, the strong desire to build a new house of worship.

In August 1859, Manuel Fernandes forwarded a request to the Diocesan Bishop D. Antônio José de Melo, to place a baptismal font in the chapel. Supported by the local population, the Bishop authorized the construction of the baptismal providing it was located in a "decent" place. In 1861, the resident Maria Felizarda made a large donation in honor of São Sebastião. This donation possibly instigated the vestryman of the building of a new parish church to increase the speed in which the region was developing. In 1862, permission to build a new chapel on the left side of the stream of Palmeiras was granted by the Bishop of São Paulo, a location that guaranteed diocesan provisions and patrimony

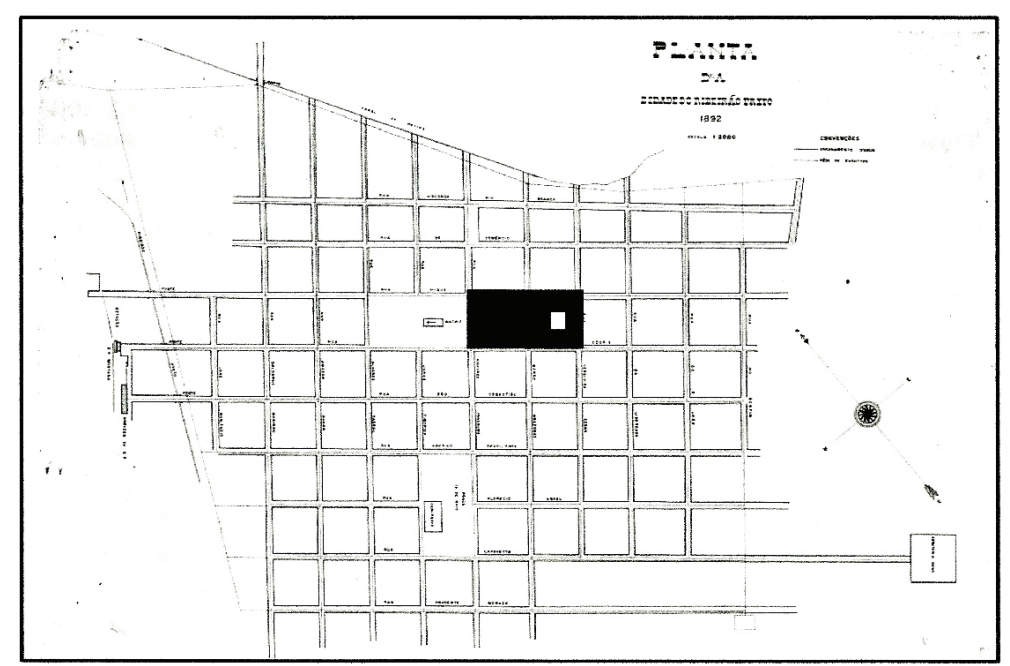

Fig. 2 One interpretation, referring to the block highlighted by the black rectangle where the first chapel in Ribeirão Preto was located, in the center in white on the City Plan, is credited to the Engineer Olímpio Antunes. It was built in 1892 as part of the studies for the implantation of sewage and supply networks (Public Archives and History of Ribeirão Preto). 
legalized by the court.

Interests and disputes among residents of Barra do Retiro led the priest Manuel Euzébio de Araújo, under the guidance of the priest Jeremias José Nogueira, to demarcate a new location for the construction of the new church. The place was chosen in the patrimonial area of São Sebastião do Ribeirão Preto, where the 15 de Novembro Square is currently located. According to Laureano [27], while "buildings were erected, the population of the village gradually increased, to the point of having 3,000 or even 4,000 inhabitants as others assert" (Fig. 3). The plots of land granted within the patrimony were placed under the institute of long lease in accordance with the descriptive request of land from the City Council, which was documented in August 1882.

The role of the vestryman as a street architect and as the organizer of the orthogonal layout of the original urban form of Ribeirão Preto was of great importance. Proof of this importance was substantiated with the murder of the vestryman Manuel Fernandes do Nascimento on February 10, 1867 by a wealthy merchant, Manuel Soares de Castilho, because the vestryman had determined, without the merchant's consent, to run a street through his backyard.

The rapid growth of the town was considerable. On July 2, 1870, the President of the Province of São Paulo, Dr. Antônio Cândido da Rocha, elevated Ribeirão Preto to the category of parish through Provincial Law 51. On July 16, 1870, the Vicar of São Paulo, Monsignor Dr. Joaquim Manoel Gonçalves de Andrade, signed the decree creating the Parish of São Sebastião do Ribeirão Preto, and confirming as the first vicar priest Joseph Philidory Torres.

The Provincial Law 67 of April 12, 1871 elevated the parish to a village, whose territory was then dismembered from the town of São Simão. Its first board was elected on February 22, 1874 and installed on June 4 of the same year.

In 1883, the tracks of the Mogiana Railroad Company reached the village of Ribeirão Preto. From this moment on, the economic, social and cultural contexts had a major impact on the future of this area. The Church no longer defined the morphology of the village, but instead, the Mogiana Railroad Company and the railway station built on the right side of the heritage lands next to the stream of Ribeirão Preto,

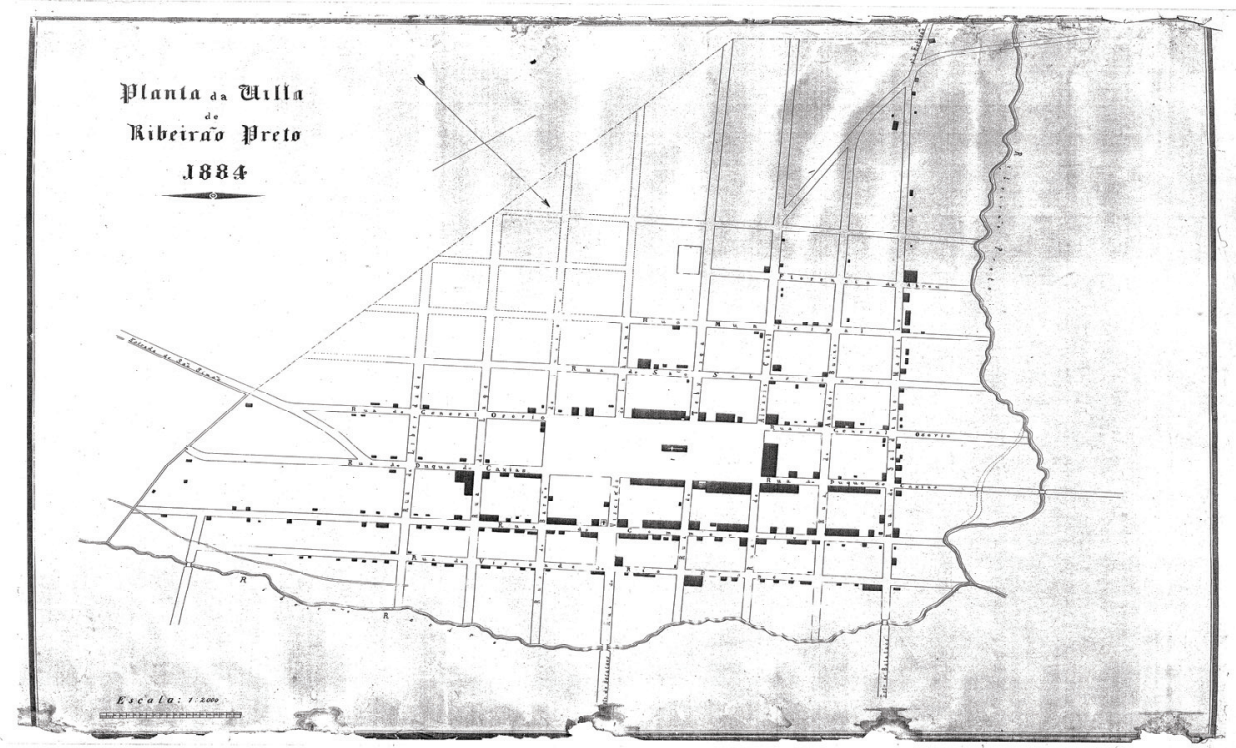

Fig. 3 The village plan of Ribeirão Preto, 1884.

The urban structure has, as a guiding point, the Church, which is located in the center of a large open space. Around the church and nearby are the first buildings on tenured plots (Public and Historical Archives of Ribeirão Preto). 
currently channeled because of the construction of Jerônimo Gonçalves Avenue, began to dominate the land and its morphology. During the transition between the 1870 s and 1880s, Ribeirão Preto joined the pioneer front of coffee production, which had as a condition the private ownership of the land. As the land turned into capital, the social relations were regulated by the commodity. "These relations do not end in the personal contact sphere anymore. The functioning of the market is the regulator of wealth and poverty" [15].

The interest was no longer proximity to the Church, but rather the proximity to the market and to the railway station. The railway station was the place of the loading and unloading of goods and the place of arrival and departure of people, thus it became a new meeting point, a place where ideas, ideals and culture were discussed and created. In the Books of Tenure of the Archdiocesan Curia of Ribeirão Preto, we observed the continual applications for tenured plots that were located next to the Mogiana rails and controlled by the Church (Fig. 4).

In addition to the rise of coffee barons, there was also a new class of immigrant settlers who came to Brazil to replace slave labor. The concept of market capitalization of production is well illustrated in this context, as shown in Fig. 4, where it is possible to identify a latent occupation in the region.

Ribeirão Preto played an important role in the national and international scene as a major producer of coffee. The major local landowners, general population and small groups of religious people organized a construction committee to raise funds for the construction of a new main church in a new location beginning in 1900. This commission was formed by priest Joaquim Antônio de Siqueira as the president and Francisco Schmidt, the owner of one of the largest coffee producing areas, as vice-president as

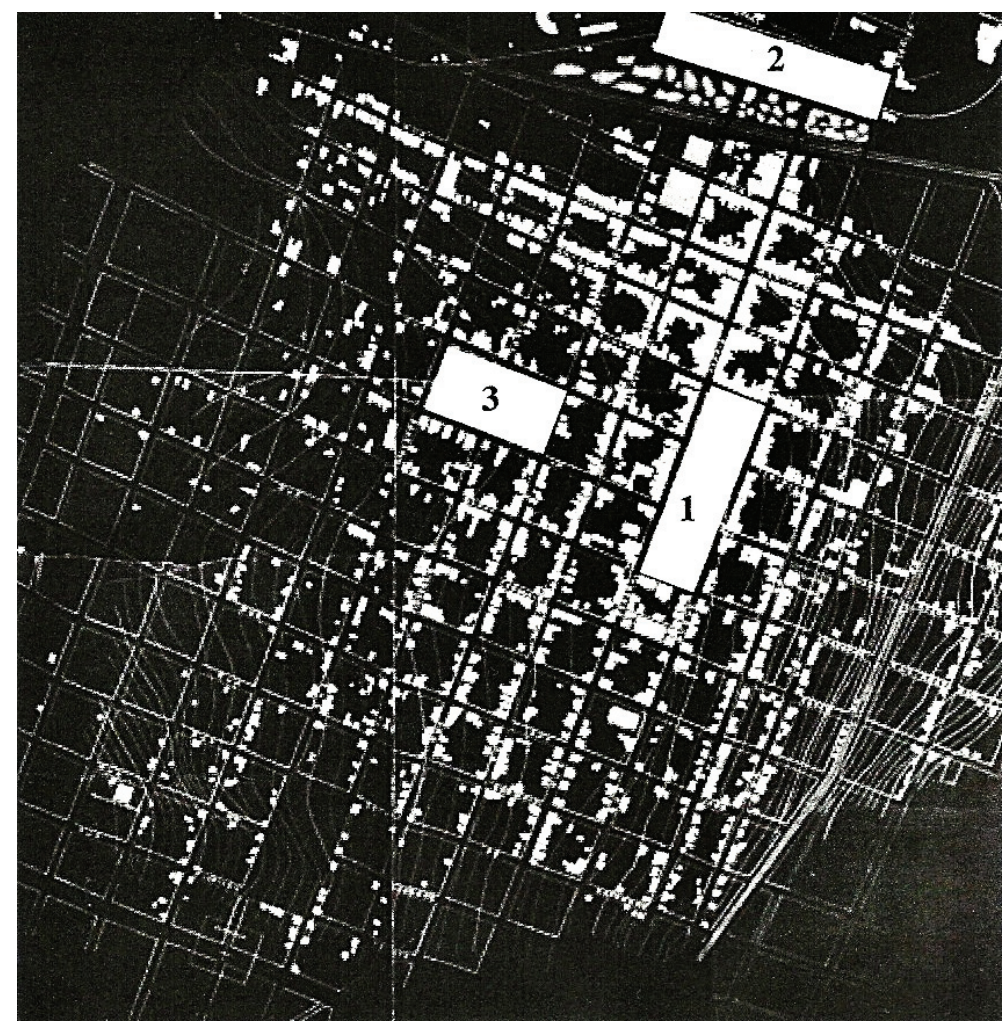

Fig. 4 Detail of the City Plan of Ribeirão Preto as organized by the office of the Light Company, 1911 1914.

In this detail of the religious heritage, it is possible to identify the three places: (1) the old square of the main church; (2) at the top of the plan, the buildings of the Mogiana Company, and in the nearby blocks, the occupation of the tenured lands; (3) at the left side at the top, 13 de Maio Square, where now stands the Cathedral (Public and Historical Archives Ribeirão Preto). 


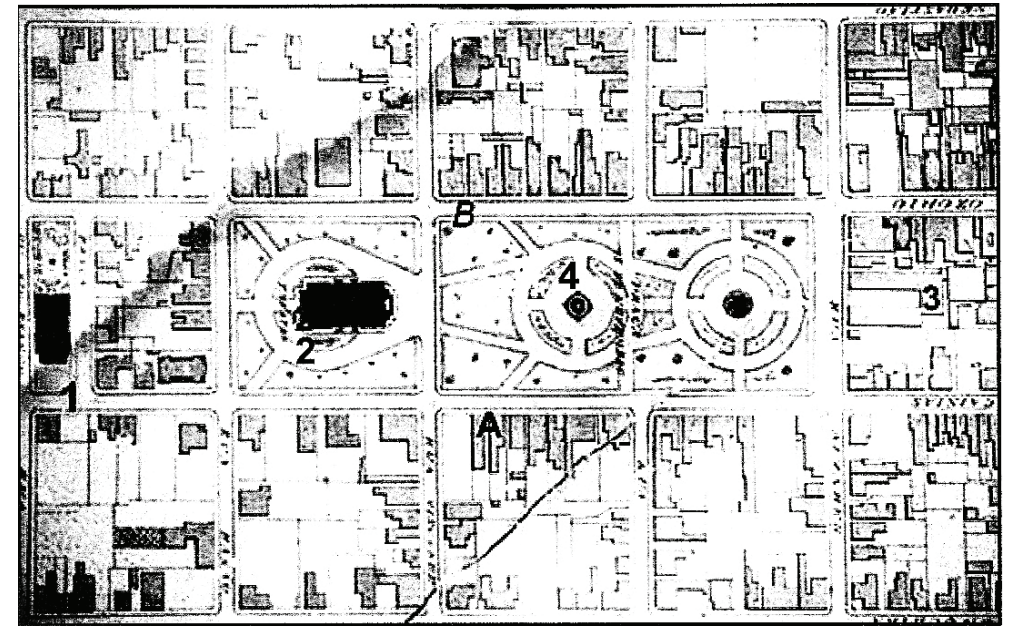

Fig. 5 Detail of the city plan of Ribeirão Preto.

In the 1930s, the ancient Main Church Square, where Praça XV de Novembro is located today, is highlighted, and it is possible to see the settings of the tenured plots of land and buildings thereon. Standing out in the Rio Branco Palace: (1) is the Carlos Gomes Theatre (now demolished); (2) the Central Hotel (now demolished); (3) the location of the former Main Church; (4) the Duque de Caxias street (A) and General Osório Street (B) (Public and Historical Archives of Ribeirão Preto).

well as other important members of the city of Ribeirão Preto.

Furthering the studies of the urban morphological structure of Ribeirão Preto through the development of the tenured land, it is possible to observe, according to surveys found in the books of tenure of the Archdiocese of Ribeirão Preto, certain irregularities in the dimensions of the land. According to a book on tenured lands from 1929, which transcribes the tenured lands since the 1870s, a wide range was identified. Examples of such irregularities include measurements of areas $17.20 \mathrm{~m}$ wide by $23.70 \mathrm{~m}$ long; $7.00 \mathrm{~m}$ wide by $23.00 \mathrm{~m}$ long; $11.00 \mathrm{~m}$ wide by $23.00 \mathrm{~m}$ long; $9.80 \mathrm{~m}$ wide by $27.00 \mathrm{~m}$ long; $20.50 \mathrm{~m}$ wide by $44.10 \mathrm{~m}$ long; and $11.40 \mathrm{~m}$ wide by $24.45 \mathrm{~m}$ long, as well as other plots of land that did not have the geometric shape of a rectangle (Fig. 5).

According to Garcia [25], the granting of lots within the religious heritage of Ribeirão Preto was integrated within the process of the formation of the city, which is common in any urban form where ecclesiastical heritage was responsible for officiating the distribution of the lands. Garcia [24] added that this process in Ribeirão Preto was further linked to the creation of a land market. Therefore, the original land structure of the city had undergone changes in form, a fact that was not restricted to drawings or factors, but rather to the modeling agents who, through social articulations, made their greatest contribution to the morphological constitution of Ribeirão Preto.

\section{Conclusions}

Urban science can not be analyzed and understood from a single academic perspective. Urban science comprises interdisciplinary research from the social sciences, humanities and exact sciences. The present study of urban morphology does not attempt to analyze a city's physical form solely by form but by the interactions, relationships and tensions between the modeling agents, especially the Church, which was largely responsible for the structure, shape and transformation of Brazilian cities.

The formation of religious heritage in Brazil and the tenure of Brazillian lands was a tentative but determined procedure in configuring urban forms in many cities. Long leases, which aimed to bring residents together for work, became a modeling agent for cities.

This case study crystallizes the conjuncture of parsimonious rules for founding cities in Brazil. Tensions began with land grants for forming religious heritage, the original urban area of the city, 
discussions on the first chapel location, and changes in location in land granted to residents by the Church. Long lease, a law that grants only the right to use urban land to the purchaser, was the recurrent land distribution system in the city of Ribeirão Preto. In this system, the property remains the responsibility of the Church.

The city of Ribeirão Preto is an example of the reminiscent appeal to the institute of long lease in urban formation and the crystallization of the context of Brazilian colonization.

In Brazilian colonial cities (1500 1822), religious heritage was a common element in configuring urban form. Starting from the imperial period (1822 1889), new rules were imposed to distribute urban land to form private ownership in a capitalist economy. However, in places where the power of the clergy overlapped with civil power, the heritage of some Brazilian cities remained with the Church.

In the Republican period (1889 1930), the Church continued to manage urban land in some Brazilian cities. In many cities belonging to the Bishopric of Ribeirão Preto, the Church maintains power in regulating urban land. In this region, many cities, including Ribeirão Preto, have their central urban area regulated by the Church.

This central area of Ribeirão Preto has the same religious heritage that was established between 1852 and 1856. The initial Ribeirão Preto settlement was founded in 1870. In this area of donated land, the residents do not own the property on which they live and pay for the Church, which owns the urban land. This land remains under tenure, as during the colonial period.

In the nineteenth century, when ownership urban land changed, taking possession of unoccupied and uncultivated land became a priority among individuals who sought to settle in the city. In Ribeirão Preto and cities in its metropolitan region, which is under the religious administration of the Bishopric of Ribeirão Preto, inhabitants of the urban center adopted a strategy to legitimize and regularize land tenure.

The present study illustrates the strategies of residents for occupying urban land. Although these lands are regulated by the Church, many residents have sought to appropriate this urban territory, even if they are required to pay the courts and do not have ownership of the land or building, only tenure. The most avid residents requested that the Church concede several lots to the same family using children and other relatives to regularize this request. Because ownership implies use of the property, the same person cannot request more lots. This strategy was used to accumulate properties and was typical in capitalist cities.

The vestryman, a Church employee, formed the streets, distributed lots and administered the religious patrimony of the Church. This case study in Ribeirão Preto reveals the importance of the vestryman as head of urban layout and in deciding the locations of new streets. In the beginning of this process, the area surrounding the Church was privileged.

When the railroad arrived in Ribeirão Preto in 1883, the city became part of a pioneering front for coffee export. New blocks and streets were defined around the train station by the vestryman. This new urban area initiated growing interest from residents to obtain lots donated by the Church. The train station halls attracted new urban land and became a site not only for loading and unloading goods but also as a new meeting point to circulate ideas, ideals and culture.

The institute of long lease has existed in Brazil since the colonial period, but the Civil Code of 1916 and the latest in 2002 abolished long lease for new properties. However, despite these codes, the maintenance of tenure of urban land, especially in areas of religious heritage, such as in Ribeirão Preto, is still administered by the Church, which keeps the land as a vested right. Thus, the urban land of a city of one million inhabitants, the center of a modern agro-industrial economy, is administered by the Church, similar to the colonial period. This case study 
sought to demonstrate how archaic land structures survive in modern cities. This phenomenon has not yet been evaluated in other Brazilian cities [19, 28, 29].

\section{Acknowledgments}

The authors wish to thank the FAPESP (Research Founding Agency of São Paulo State), the CNPq (Brazilian Research Council) and the CAPES (Brazilian Coordination for the Education Improvement of Higher Level) for the financial support.

\section{References}

[1] Lepetit, B. 2001. To a New Urban History. São Paulo: University of Sao Paulo Publisher. (in Portuguese)

[2] Kropft, K. 2009. "Aspects of Urban Form.” Journal of the International Seminar on Urban Form 13: 105-20.

[3] Moraes, A. C. R. 2005. Territory and History in Brazil. São Paulo: Annablume. (in Portuguese)

[4] Lynch, K. 1981. Good City Form. Cambridge: MIT (Massachusetts Institute of Technology) Press.

[5] Vanconcelos, P. A. 2009. Modelers Agents of the Colonial Cities in L. Pessotti; NP Ribeiro, Colonial Urbanism: Towns and Cities of Portuguese. Rio de Janeiro: Matrix Press, 10-25. (in Portuguese)

[6] Oliveira, V. 2013. "Morpho: A Methodology for Assessing Urban Form." Journal of the International Seminar on Urban Form 17: 21-33.

[7] Gil, J., Beirão, J. N., Montenegro, N., and Duarte, J. P. 2012. "On the Discovery of Urban Typologies: Data Mining the Many Dimensions of Urban Form." Journal of the International Seminar on Urban Form 16: 27-40.

[8] Whitehand, J. W. R. 2012. "Issues in Urban Morphology." Journal of the International Seminar on Urban Form 16: 55-65.

[9] Kim, K. J. 2012. "The Study of Urban Form in South Korea." Journal of the International Seminar on Urban Form 16: 149-64.

[10] Ehlers, E. 2011. "City Models in Theory and Practice: A Cross-Cultural Perspective." Journal of the International Seminar on Urban Form 15: 97-119.

[11] Lamas, J. M. R. 2010. Urban Morphology and Design of the City. Lisbon: Foundation Calouste Gulbenkian. (in Portuguese)

[12] Marx, M. 1991. City in Brazil: Land of Who?. São Paulo: Nobel: University Press. (in Portuguese)

[13] Fonseca, C. D. 2011. Camps and Villages D'el King, Space and Power in the Eighteenth Century Minas. Belo
Horizonte: UFMG (Universidade Federal de Minas Gerais). (in Portuguese)

[14] Derntl, M. F. 2013. Method and Art: Urbanization and Territorial Formation in the Province of Sao Paulo, 1765 1811. Sao Paulo: Alameda Press. (in Portuguese)

[15] Lages, J. A. 1996. From Figueira to Barra of Retiro-The Settlement of the Region by Incoming Miners in the First Half of the Nineteenth Century. Ribeirao Preto: VCA Publishing and Printing. (in Portuguese)

[16] Abreu, M. A. 2006. "The Appropriation of Land in Colonial Brazil." In IE de Castro (et al.) Geographic Explorations. Rio de Janeiro: Bertrand Brazil. (in Portuguese)

[17] Ghirardello, N. 2010. The Formation of the Religious Heritage in the Sao Paulo: Urban Expansion Process 1850 1900. São Paulo: UNESP (Universidade Estadual Paulista). (in Portuguese)

[18] Vide, D. S. M. 1853. First Constitutions of the Archbishopric of Bahia. Sao Paulo: Typographia Press. (in Portuguese)

[19] Piccinato Jr., D., and Salgado, I. 2012. "Urban Land: The Relationship of Religious and Public Institutions in Control of the Original Land Heritage of the City of Buritizal/SP." Notebooks PROARQ (UFRJ) 18: 35-47. (in Portuguese)

[20] Marx, M. 1980. Brazilian City. São Paulo: Melhoramentos and São Paulo University Press. (in Portuguese)

[21] Teixeira, M. C. 2011. Brazilian Urban Models of Portuguese Cities in L. Pessoti; NP Ribeiro, Construction of the Portuguese City in America. Rio de Janeiro: PoD Publishing Company. (in Portuguese)

[22] Monteiro, W. B. 1953. Civil Law Course: Property Law. São Paulo: Saraiva. (in Portuguese)

[23] Amorim, E. C. 1986. Theory and Practice of Long Lease. Rio de Janeiro: Forense Press. (in Portuguese)

[24] Lima, R. C. 1990. Small Territorial History of Brazil: Allotments and Vacant Lands. Sao Paulo: State Department of Culture. (in Portuguese)

[25] Garcia, V. E. 2013. "The Holy? Or Who... Ribeirão Preto: Genesis of Merchandise City.” Ph.D. thesis, Architecture and Urbanism Institute, University of São Paulo. (in Portuguese)

[26] Costa, O. E. 1955. History of Ribeirão Preto. São Paulo: Foundation Collection History Magazine. São Paulo. (in Portuguese)

[27] Laureano, J. 1973. Subsidies for the Religious History of Ribeirão Preto. Ribeirão Preto: Metropolitan Curia of Ribeirão Preto. (in Portuguese)

[28] Piccinato Jr., D., and Salgado, I. 2014. "Urban Conflict: The Difficult Relation between the Church and the Municipality in the Management of the Urban Land in 
Brazil." In Proceedings of the 16th International Planning History Society Conference, 890-903.

[29] Piccinato Jr., D. 2012. "Urban Land, Land Heritage: An Historical Analysis of Land Ownership in the Urban
Setting in the Northeast of São Paulo (1800 1930)." Master thesis, School of Architecture and Urban Planning, Pontifical Catholic University of Campinas. (in Portuguese) 